Semina $\square \quad \mathrm{Nr} 15$

Scientiarum 2016

s. $88-106$

DOI: http://dx.doi.org/10.15633/ss.1770

Michał Kłusek

\title{
Modelowanie akrazji
}

Economics must overcome the prejudice that behavior is real but thoughts are not $^{1}$.

Robert Cooter

Akrasia (z greckiego „brak opanowania”) oznacza sytuację, w której osoba postępuje wbrew własnej ocenie tego, co dobre. Wiedzac, co dobre, wybiera coś innego. Sytuację tą można opisać w następujący sposób: Jednostka czyni $A$ zamiast $B$, pomimo że jest przekonana, że biorac wszystko pod uwagę, $b$ jest lepszym wyborem.

Zdaniem Sokratesa taka sytuacja jest niemożliwa. „[...] nikt, jeśli bądź to wie, bądź to myśli, że coś innego jest lepsze niż to, co on robi i ono jest mu dostępne, nie będzie robił źle, mogąc robić to, co lepsze"2. $\mathrm{Z}$ takim poglądem zdecydowanie nie zgadzał się Arystoteles. Jego zdaniem akrasia (brak opanowania) może wynikać z dwóch przyczyn: popędliwości (propeteia) lub słabości (astheneia). Osoby popędliwe ignorują głos rozsądku, kierując się impulsem chwili, „[...] dają się porwać namiętności, ponieważ wcale nie namyślili się”3. Osoby słabe rozmyślają nad tym, co dobre, a mimo to postępują wbrew swojej wiedzy, pod wpływem namiętności.

1 R. Cooter, Lapses, conflict and akrasia in torts and crimes, "International Review of Law and Economics" 1991, http://works.bepress.com/robert_cooter/95/ (13.02.2016)

2 Platon, Protagoras, [w:] Platon, Dialogi, t. 1, Kęty 1999, s. 326.

3 Arystoteles, Etyka nikomachejska, przeł., oprac. i wstępem poprzedziła D. Gromska, Warszawa 1982, s. 260. 
Klasyczny ekonomiczny model decyzji jest znacznie bliższy myśli Sokratesa. Homo oeconomicus ma określone, spójne i przechodnie preferencje, które pozwalają mu wybierać te działania, które w największym stopniu zaspokoją jego potrzeby. Wie, czego chce, i właśnie to wybiera. W tym modelu nie ma miejsca na postępowanie „wbrew” swoim preferencjom. Wewnętrzne konflikty, wahania i żal związany z określonym wyborem pozostają na ogół poza zainteresowaniem (i możliwościami) analizy ekonomicznej. Model akrazji Roberta Cootera jest bardzo interesująca próbą wypełnienia tej pustki. Rozszerza obszar zainteresowania ekonomii z zewnętrznych działań (będących emanacją preferencji) na proces decyzyjny prowadzący do tych działań.

Celem pracy jest opisanie modelu, a następnie zastawienie go z antycznymi i współczesnymi filozoficznymi koncepcjami akrazji, a także analiza tego, w jakiej mierze daje się on z nimi połączyć. Zacznę od przedstawienia podstaw teorii racjonalnego wyboru i teorii użyteczności, następnie przedstawię trzy wariacje modelu błędów (lapses), tj. działań pod wpływem chwilowego impulsu znacznie odbiegajacego od typowych preferencji jednostki. Następnie opisany zostanie model oczekiwanego żalu (regret) związanego z określona decyzja, a także to, jak model Roberta Cootera da się połaczyć ze współczesnymi filozoficznymi koncepcjami akrazji. Tego typu połączenie pozwala przedstawić pełniejszy obraz wspomnianego zjawiska. Filozoficzne interpretacje w oderwaniu od ekonomicznego modelu nie moga być bezpośrednio zastosowane w analizie ekonomicznej; jednocześnie sam model akrazji, pozbawiony filozoficznej podbudowy, nie w pełni opisuje naturę tego zjawiska, zostawiając wiele pytań bez odpowiedzi.

\section{Teoria wyboru konsumenta}

Dla zrozumienia modelowania akrazji przez Roberta Cootera konieczne jest przypomnienie podstaw teorii wyboru konsumenta. Podstawowe pojęcie w tej teorii to pojęcie użyteczności - tj. miary satysfakcji, jaką jednostka czerpie z konsumpcji określonych dóbr 
i usług. Nie należy rozumieć jej jako psychologicznej wielkości dającej się mierzyć. Jest to teoretyczny konstrukt, pozwalający na wyrażenie preferencji jednostki wybierającej spośród zestawu dóbr. Teoria wyboru konsumenta opiera się na założeniu, że jednostka maksymalizuje swoją funkcję użyteczności. Wybierając z zestawu dóbr (usług), wybiera te, z którym wiąże się największa użyteczność (satysfakcja). Użyteczność jest „tym, co reprezentuje preferencje”. Jeśli jednostka preferuje dobro ponad dobro, możemy powiedzieć, że z dobrem związana jest większa użyteczność niż z dobrem. Przyporządkowując różnym koszykom dóbr wartość użyteczności, która jednostka z nimi wiąże, możemy stworzyć funkcję użyteczności danej jednostki. Rzecz jasna, maksymalizując swoją funkcję użyteczności, jest ona ograniczona przez „warunki zewnętrzne”, np. ograniczoną dostępność dóbr.

Krzywa obojętności łączy kombinacje dóbr, którym jednostka przypisuje równą miarę użyteczności. Z preferencjami jednostki wiąże się kilka dodatkowych założeń. Po pierwsze, są one zupełne, tj. w każdym przypadku wyboru pomiędzy $A$ i $B$ jednostka potrafi określić, które z nich preferuje (lub czy jest to dla niej obojętne). Po drugie, są one przechodnie, co oznacza, że w sytuacji, gdy jednostka preferuje $A$ względem $B$ i $B$ względem $C$, to nie może być tak, że preferuje $C$ ponad $A$.

Tak rozumianą teorię wyboru konsumenta możemy rozszerzyć (jak czyni to Cooter) z dóbr i usług na wszystkie „stany świata” lub działania. Dla każdego działania (dobra) stanu świata jednostka jest w stanie przyporządkować określoną miarę użyteczności. Te miary użyteczności pozwalają następnie uszeregować te dobra według preferencji.

\section{Model błędów - konsumpcja i inwestycje}

Przechodząc do opisu modelu akrazji, należy zacząć od prostego modelu decyzji. Jednostka postawiona jest przed wyborem: może

4 J. Broome, Ethics out of economics, Cambridge 1999, s. 28. 
wybrać konsumpcję o wartości 1 lub zainwestować te same środki i w efekcie uzyskać korzyść równą $b$.

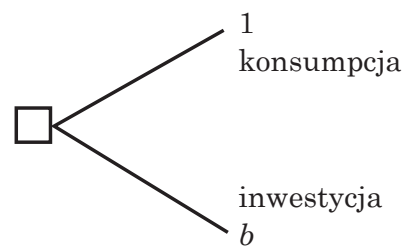

Rys. 1. Źródło: R. Cooter, Justice and economic decision making: a model of akrasia, „Social Justice Research” 1990, s. 276.

Zakładamy, że $b$ jest znacznie wyższy od $1, b \gg 1$, zatem racjonalna osoba wybierze inwestycję. Jednocześnie jednak korzyść płynacca $\mathrm{z}$ inwestycji jest odsunięta w czasie, zatem jej subiektywna wartość będzie odpowiednio mniejsza. By to wyrazić, wartość wspomnianej korzyści jest zmniejszona przez stopę dyskontową $r$. A zatem w rzeczywistości jednostka maksymalizuje swoją korzyść, wybierając między 1 i $b / r$

$$
\max (1, b / r)
$$

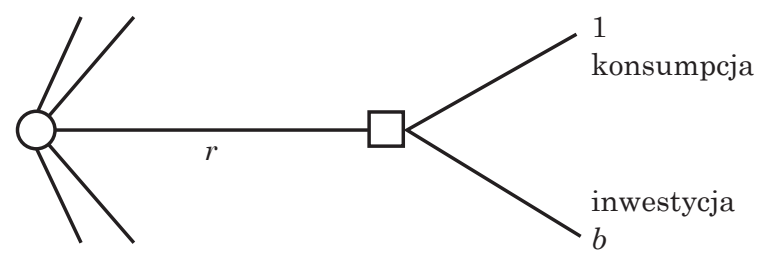

Rys. 2. Źródło: R. Cooter, Justice and economic decision making: a model of akrasia, „Social Justice Research” 1990, s. 277.

To, w jakim stopniu dana osoba dyskontuje przyszłe korzyści (lub koszty), jest różne dla różnych osób, a także zmienne w czasie. Wysokość $r$ zależy od bardzo wielu czynników, emocji, nastroju lub sytuacji majątkowej w danej chwili. Na potrzeby tego modelu zakła- 
damy, że jest ona losowa. Zatem przed podjęciem decyzji jednostka pobiera swoją stopę dyskontową $r$ z rozkładu prawdopodobieństwa $p(r)$. Zakładamy także, że rozkład prawdopodobieństwa jest rozkładem normalnym. Stopę dyskontowa, która jednostka posługuje się przy podjęciu decyzji będziemy określać jako $r_{0}$.

$$
\max \left(1, b / r_{0}\right)
$$

Co za tym idzie, w sytuacji gdy $b / r_{0}$ jest większe od 1 , jednostka wybierze inwestowanie. W sytuacji gdy $b / r_{0}$ jest mniejsze od 1 , jednostka wybierze natychmiastową konsumpcję. W związku z tym musi istnieć wartość $r^{*}$, dla której $b / r^{*}=1$ (tipping point). W sytuacji gdy $r_{0}>r^{*}$, jednostka wybiera konsumpcję, gdy $r_{0}<r^{*}$, wybiera inwestycję. Wartość $b$ jest znacznie wyższa od 1 , a zatem wartość $r$ * musi być odpowiednio wysoka, by w wystarczajacym stopniu zmniejszyć subiektywne odczucie korzyści z inwestowania poniżej 1. Możemy zatem założyć, że co do zasady stopa dyskontowa $r$ pobrana z $p(r)$ będzie mniejsza od $r^{*}$.

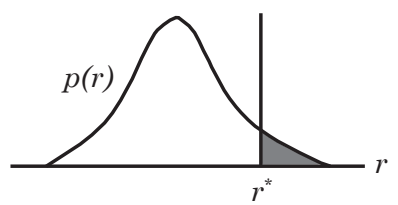

Rys. 3. Źródło: R. Cooter, Justice and economic decision making: a model of akrasia, „Social Justice Research” 1990, s. 278.

W takim wypadku konsumpcja będzie stanowiła błąd (lapse). Prawdopodobieństwo popełnienia błędu (czyli $r_{0}$ przekraczającego $r^{*}$ ) jest równe gęstości na prawo od $r^{*}$ (zacieniony obszar na rysunku).

\section{Model błędów - sprawiedliwość dystrybucyjna}

W prosty sposób Cooter przenosi wyżej opisane rozumowanie na grunt sprawiedliwości dystrybucyjnej. W tym przypadku zakładamy, 
że 1 wyraża naszą własną korzyść płynąca z określonego działania, zaś $b$ wyraża korzyść płynąca z działania dla innych osób. Ponownie $b \gg 1$. Jednostka staje przed wyborem działania egoistycznego (self-regarding act) lub działania, które przyniesie korzyść (również) innym osobom (other-regarding act). Nie zagłębiając się w szczegóły takiej teorii sprawiedliwości, możemy pozostać przy prostym rozumowaniu, że w przypadku gdy $b \gg 1$, właściwe jest działanie sprzyjające innym.

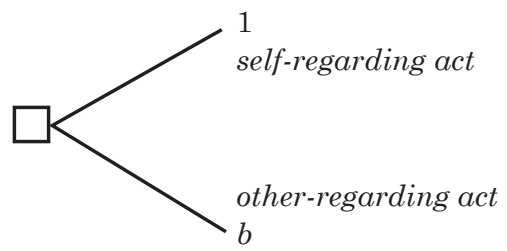

Rys. 4. Źródło: opracowanie własne.

Tym niemniej, podobnie jak w pierwszym przypadku, wartość $b$ jest dyskontowana, w tym przypadku z uwagi na to, że korzyść odnoszą inne osoby, a nie sama jednostka. Zatem ponownie mamy do czynienia z sytuacja:

$$
\max \left(1, b / r_{0}\right)
$$

Zakładamy, że $b$ znacznie przewyższa 1 , a zatem w większości przypadków jednostka postapi sprawiedliwie i wybierze działanie przynoszące korzyść innym osobom (other-regarding act). Oczywiście nadal stopa dyskontowa $r$ pobierana jest z $p(r)$, a także istnieje $r^{*}$, przy którym $b / r^{*}=1$. W sytuacji gdy $r$ jest mniejsze od $r^{*}$, osoba wybierze działanie sprzyjajace innym. Jeśli $r$ przekracza $r^{*}$, wybierze działanie egoistyczne (self-regarding act).

\section{Model błędów - przestępstwa}

Do tej pory używaliśmy modelu błędów w dwóch przypadkach: w sytuacji wyboru między natychmiastową konsumpcją a inwestowa- 
niem, i sytuacji wyboru między działaniem wyłącznie na własna korzyść i działaniem sprzyjajacym innym. Model ten można również zastosować do opisywania zachowań przestępczych (w tej wersji jest on najbardziej użyteczny dla ekonomicznej analizy prawa).

W przypadku gdy jednostka staje przed wyborem popełnienia przestępstwa, opcje wyglądają następujacco: niedziałanie (0), lub działanie - popełnienie przestępstwa. Z działaniem wiążą się pewna $b$ oraz kara (koszt) $c$. Kara jednak nie jest pewna, zostanie wykonana tylko w przypadku skazania za popełnienie przestępstwa. Mamy zatem do czynienia z karą oczekiwana, w której wysokość kary $c$ mnoży się przez prawdopodobieństwo jej wykonania $p$. Co za tym idzie, oczekiwana wartość popełnienia przestępstwa $(E V)$ jest równa:

$$
E V=b-p c
$$

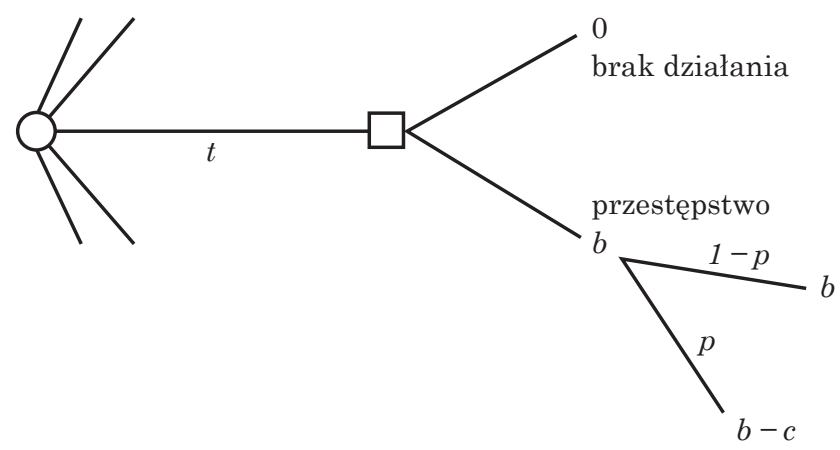

Rys. 5. Źródło: R. Cooter Lapses, conflict and akrasia in torts and crimes, „International Review of Law and Economics" 1991, s. 151.

Zakładamy, że $p c$ jest znacznie wyższe od $b$, a zatem $E V<0$. Co za tym idzie, co do zasady jednostka nie będzie popełniać przestępstw. Przestępstwa sa bardzo ryzykowne. W tym przypadku to, czy osoba popełni przestępstwo, będzie zależało od preferencji do ryzyka $r$. Zatem tak naprawdę mamy do czynienia z sytuacją:

$$
E V=b-p c / r
$$


Wartość preferencji ryzyka $r$ zależy od obiektywnego ryzyka, opisywanego jako wariancja kosztów $\left(\sigma^{2}\right)$ i subiektywnej preferencji ryzyka $t$. Zatem

$$
r=\left(\sigma^{2}, t\right)
$$

W tym przypadku parametr $t$ jest pobierany z rozkładu prawdopodobieństwa $f t$ ), analogicznie do stopy procentowej $r$ we wcześniejszych przykładach. Jego wartość $t=0$ oznacza neutralność wobec ryzyka, $t<0$ oznacza awersję do ryzyka, $t>0$ odpowiada preferencji ryzyka. $t$ będzie mniejsze od 0 , wartość $t>0$ jest mało prawdopodobna. Analogicznie do poprzednich przykładów istnieje wartość $t^{*}$, przy której jednostce jest obojętne, czy popełni przestępstwo, czy nie. Zatem dla $t^{*}$ :

$$
\left.0=b-p c / r s^{2}, t^{*}\right)
$$

Dla $t<t^{*}$ osoba nie popełnia przestępstwa, dla $t \geq t^{*}$ ryzykuje i popełnia przestępstwo.. W tym miejscu należy zwrócić uwagę na fakt, że w modelu mamy do czynienia z przestępstwami bardzo ryzykownymi, zatem $E V \ll 0$, a musi znacznie przewyższać 0, by doszło do popełnienia przestępstwa. Tym samym $t^{*} \gg 0$. Można wyobrazić sobie sytuacje przestępstw mniej ryzykownych, które (zgodnie z tym modelem) będą popełniać również osoby z awersją do ryzyka $(t<0)$. Podobnie jak w poprzednich przykładach, również w tym wypadku prawdopodobieństwo popełnienia przestępstwa odpowiada gęstości rozkładu prawdopodobieństwa na prawo od $t^{*}$ (por. rys. 3).

Naturalnie, podobnie jak w poprzednich przykładach, również tutaj możemy przyjać zamiast preferencji ryzyka np. preferencję do przyszłości (pozostając przy konsekwencjach popełnienia przestępstwa w postaci ryzyka poniesienia kary).

\section{Model żalu}

Do tej pory modelowaliśmy błędy (lapses), tj. sytuacje, w których jednostka podejmuje w danej chwili decyzje pod wpływem nieprzeciętnie wysokiej stopy dyskontowej. Innymi słowy na ogół postapi- 
łaby inaczej (np. nie popełniła przestępstwa). Korzystając jednak jedynie z modelu błędów, nie możemy jeszcze modelować akrazji, to znaczy sytuacji, w której:

Jednostka czyni $a$ zamiast $b$, pomimo że jest przekonana, że biorąc wszystko pod uwagę, $a$ jest lepszym wyborem.

By móc modelować taką sytuację, musimy wprowadzić element „przekonania”, że inny wybór jest (byłby) lepszy.

Oryginalność modelu akrazji Roberta Cootera polega na modelowaniu preferencji zmiennych w czasie. Od momentu podjęcia (dowolnej z powyższych) decyzji upłynie pewien czas, zanim zrealizuja się korzyści $b$. Stopa dyskontowa $r$ jest zmienna w czasie. By to modelować, zakładamy, że jednostka pobiera $r$ po raz drugi. Będziemy ją oznaczać jako $r_{1}$ (w przeciwieństwie do pierwszej stopy dyskontowej $r_{0}$ ). W momencie podejmowania decyzji wyboru między 1 i $b$ jednostka zna wartość stopy dyskontowej $r_{0}$, ale jeszcze nie $r_{1}$. Tym niemniej wybiegając myślami w przyszłość wie, że może być ona inna. Biorac pod uwagę, że stopa dyskontowa $r_{0}$ znacznie odbiega od średniej, może się spodziewać, że $r_{1}$ będzie bliższe środka rozkładu prawdopodobieństwa i $r_{1}<r^{*}$. W tym miejscu pojawia się konflikt między motywacjami chwili i ewentualnym przyszłym żalem związanym z dokonaniem określonego wyboru. Żal ten pojawia się $\mathrm{w}$ momencie, gdy kierując się stopą dyskontową $r_{1}$, jednostka nie podjęłaby tej samej decyzji.

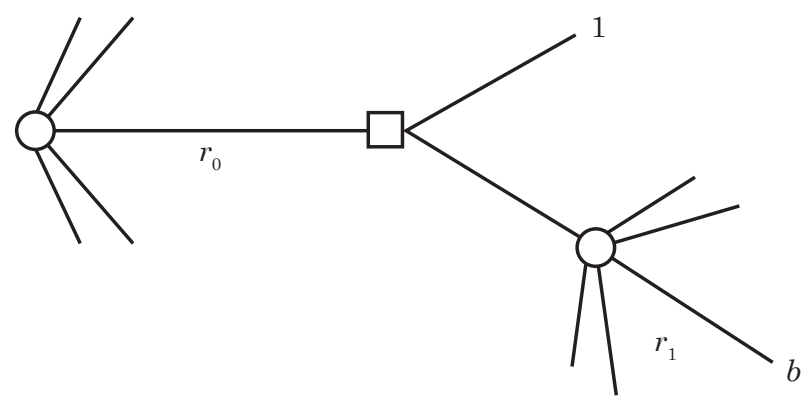

Rys. 6. Źródło: R. Cooter, Justice and economic decision making: a model of akrasia, „Social Justice Research” 1990, s. 278. 
W tym miejscu należy wprowadzić pojęcie spodziewanego żalu związanego z daną decyzją (expected regret). Jednostka może określić spodziewana przyszłą wartość ( $b$ / $r_{1}$, którą możemy oznaczyć jako:

$$
\left.E b / r_{1}\right)=\int\left(b / r_{1}\right) p\left(r_{1}\right) d r_{1}
$$

W sytuacji gdy $\left.1-E b / r_{1}\right)<0$, można oczekiwać, że w przyszłości będzie się żałować decyzji o konsumpcji. Zatem wielkość oczekiwanego żalu to $E\left(b / r_{1}\right)-1$.

Co za tym idzie osoba podejmuje decyzję wybierając między $1-b / r_{0}$ i $E\left(b / r_{1}\right)-1$. W ten sposób możemy modelować konflikt między impulsem chwili a przyszłymi przemyślanymi preferencjami. Przemyślany (considered) wybór polega na balansowaniu impulsu chwili i przyszłych preferencji, tj. wyboru dokonanego w sytuacji stopy dyskontowej $r_{1}$ i $r_{0}$. Osoba roztropna (prudent) będzie działała na bazie przemyślanych preferencji, a nie pod wpływem chwilowego impulsu. Z kolei osoba nieroztropna zna swoje przemyślane preferencje, tym niemniej postępuje wbrew nim, kierując się wyłącznie preferencjami chwili. W przypadku osoby nieroztropnej mamy oczywiście do czynienia z akrazja ${ }^{5}$. Jeśli roztropność polegała na przywiązywaniu odpowiedniej wagi do swoich obecnych $\left(r_{0}\right)$ i przyszłych $\left(r_{1}\right)$ preferencji, sprawiedliwość dystrybucyjna opiera się na przywiązywaniu odpowiedniej wagi do własnej korzyści i korzyści innych osób.

Bardziej szczegółowo możemy to przedstawić w sposób następujący, wracając do ostatniego przykładu przestępcy:

Podobnie jak w poprzednich przykładach, mamy do czynienia z dwukrotnym pobraniem $f(t)$ subiektywnych preferencji ryzyka, które będziemy określać jako $t_{0}$ i $t_{1}$. Ponownie zakładamy, że $t_{1}$ jest na tyle niższe od $t_{0}$, że kierując się „nowymi” preferencjami jednostka nie popełniłaby przestępstwa. Zatem w pierwszej chwili ekwiwalent pewności jednostki możemy opisać jako:

5 Robert Cooter posługuje się pojęciem przemyślanego wyboru (considered choice), oznaczającym wybór, który balansuje impuls chwili i oczekiwany żal, a także przemyślanych preferencji (considered preferences), oznaczającym preferencje w przyszłości (np. przy stopie dyskontowej). 


$$
C E=b-p c / r\left(\sigma^{2}, \mathrm{t}_{0}\right)
$$

Natomiast późniejszy jako:

$$
C E=b-p c / r\left(\sigma^{2}, \mathrm{t}_{1}\right)
$$

Racjonalna jednostka bierze pod uwagę zarówno siłę chwilowego impulsu, jak i przyszły żal. Zakładamy, że możemy uszeregować chwilowy impuls $(C E)$ i przyszły żal $(E R)$, tak że:

$$
w=w\left(C E\left(t_{0}\right), E R\right)
$$

W tym przypadku zarówno $w_{1} \leq 0$, jak i $w_{2} \leq 0$. Możemy sytuację konfliktu między chwilowym impulsem i przyszłym żalem przedstawić na rysunku:

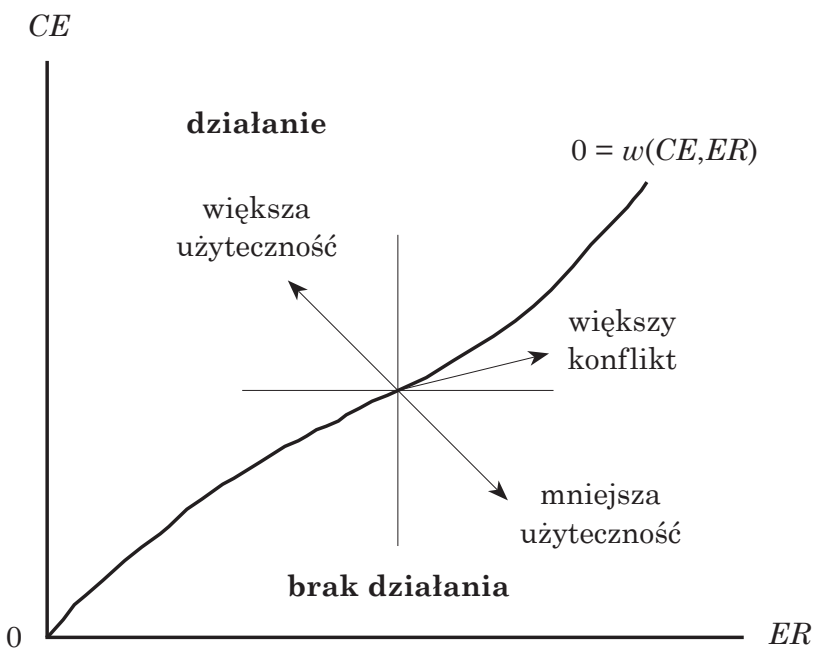

Rys. 7. Źródło: R. Cooter Lapses, conflict and akrasia in torts and crimes, „International Review of Law and Economics" 1991, s. 157.

Siła impulsu jest przedstawiona na osi pionowej, przyszły żal na osi poziomej. Niepodjęcie żadnego działania (w przykładzie prze- 
stępcy) równa się wypłacie równej 0. Możemy znormalizować tak, że $0=w(0,0)$. Co za tym idzie jednostka działa w sytuacji, gdy $w \geq 0$ i nie działa w sytuacji $w<0$. Krzywa użyteczności $w=0$ dzieli nasz wykres na dwie części. Jedna z nich odpowiada kombinacji $C E$ i $E R$, przy której osoba popełnia przestępstwo, druga kombinacji, przy której go nie popełnia. Dla wszystkich punktów powyżej krzywej obojętności bezpośredni impuls przeważa nad spodziewanym żalem.

Z powyższego dość jasno wynika, że zwiększenie przyszłego żalu będzie skutkowało zmniejszeniem liczby „błędów”. Na wykresie jasno widać, że „przeważenie” znacznego spodziewanego żalu wymaga bardzo silnego impulsu bezpośredniego. Zatem bezpośrednie preferencje będą musiały być pobrane z prawego krańca rozkładu prawdopodobieństwa. W przypadku znacznego żalu zdecydowanie częściej będziemy mieli do czynienia z brakiem działań niż z popełnieniem przestępstwa.

Możemy zatem przedstawić następująca relację między opisanym powyżej, podstawowym modelem błędów i modelem oczekiwanego żalu. W każdym przypadku istnieje wartość $t \sim$, dla której:

$$
0 w C E(t \sim, E R
$$

W przypadku gdy oczekiwany żal maleje, maleje również $t \sim$. W momencie, gdy oczekiwany żal wynosi 0 , model ten de facto zmienia się w opisywany powyżej model błędów, zatem:

$$
0=w\left(C E\left(t^{*}\right), E R\right)
$$

\section{Filozoficzne tło modelu}

Przypomnijmy:

Jednostka może popełnić niewłaściwy czyn (tj. taki, który nie maksymalizuje jej użyteczności; który nie jest dla niej najlepszy, biorąc wszystko pod uwagę) w dwóch przypadkach:

- gdy nie dokonuje przemyślanego wyboru i działa wyłącznie pod wpływem chwilowego impulsu; 
- gdy dokonuje przemyślanego wyboru (jest świadoma swoich przyszłych preferencji), tym niemniej nie wybiera działania, które maksymalizuje jej użyteczność.

W jaki sposób ten model wpisuje się w filozoficzną dyskusję na temat akrazji? Możemy opisane powyżej sytuacje odnieść do wspominanego rozróżnienia zaproponowanego przez Arystotelesa. Kierowanie się wyłącznie impulsem chwili, brak przemyślanego wyboru byłyby przykładem popędliwości (propeteia). W drugiej sytuacji mielibyśmy do czynienia ze słabością (astheneia). Tym samym w obu ma miejsce akrazja, przynajmniej tak, jak rozumie ją Arystoteles.

Odnieśmy teraz model Cootera do współczesnych koncepcji akrazji na przykładzie poglądów Richarda Hare’a i Donalda Davidsona ${ }^{6}$.

Richard Hare reprezentuje stanowisko bliższe wizji Sokratesa (,[...] nikt, jeśli bądź to wie, bądź to myśli, że coś innego jest lepsze niż to, co on robi i ono jest mu dostępne, nie będzie robił źle, mogąc robić to, co lepsze"), a także idealnie wpisujące się w klasyczny ekonomiczny model decyzji. Akrazja nie jest możliwa.

Hare zwraca uwagę na specjalny charakter sądów wartościujących (evaluative judgements). Sa to sady na temat tego, które działanie jest lepszym wyborem lub co powinniśmy zrobić. Sądy opisowe (descriptive judgement) nie mówią o tym, co jest lepsze. Opisuja jedynie pewne cechy różnych alternatyw (np. jeden produkt jest droższy od drugiego). Wyróżniającą cechą sądów wartościujących jest fakt, że wytyczają kierunek działań (guide action). Z sądem wartościującym wiąże się odpowiedź na pytanie: „Co powinienem zrobić?”. Odpowiedzią na takie pytanie może być jedynie imperatyw: „Zrobię $a$ ” (Let me do a). Z sądem wartościującym wiąże się pierwszoosobowy (first-person) imperatyw. Jeśli sąd $J_{1}$ pociaga za sobą sąd $J_{2}$, to zgoda na $J_{1}$ musi oznaczać również zgodę na $J_{2}$. Co oznacza zgoda? W przypadku sądu zgoda oznacza wiarę (believing). Zgoda na impe-

6 Poglądy Hare'a i Davidsona przytaczam w dużej mierze za: S. Stroud, Weakness of will, [w:] The Stanford encyclopedia of philosophy (Spring 2014 Edition), ed. E. N. Zalta, http://plato.stanford.edu/archives/spr2014/entries/weakness-will/ (17.05.2016). 
ratyw oznacza wykonanie określonego działania. Z tego można wyciagnaćc prosty wniosek, że o ile mam możliwość wykonania czynności $a$ i nie wykonują czynności $a$, to nie jestem w pełni przekonany, że powinienem czynić $a$. Z czyichś działań możemy w prosty sposób wywnioskować, jakie sa ich sądy wartościujące. Nie tylko możemy się ich domyślać, ale wprost je poznajemy, obserwując czyjeś działanie. W ujęciu Richarda Hare'a akrazja może (pozornie) mieć miejsce w dwóch sytuacjach: albo tak naprawdę jednostka nie wierzy, że określone działanie jest lepsze, albo nie jest w stanie działać w określony sposób. Niezdolność działania może wynikać z czynników psychologicznych. Jednostka może być opanowana przez tak silne emocje, że nie jest w stanie działać zgodnie z przekonaniem o tym, co jest dla niej najlepsze. Nie będzie to jednak akrazja w ścisłym znaczeniu tego terminu.

Pogląd Richarda Hare'a doskonale wpisuje się w klasyczne ekonomiczne rozumienie preferencji, zgodnie z którym poznajemy preferencje jednostki obserwując to, jakich dokonuje wyborów, jej zachowania. Dodajmy, w takim ujęciu preferencji jednostka nie jest w stanie postępować wbrew swoim preferencjom. Tym samym akrazja nie jest możliwa. Czy da się pogodzić poglądy Hare'a z modelem akrazji Roberta Cootera?

Niewłaściwe zachowanie w modelu Cootera może mieć miejsce w dwóch przypadkach: braku przemyślanego wyboru (arystotelesowskiej popędliwości) i przemyślanego wyboru, w którym jednak jednostka nie postępuje zgodnie z przemyślanymi preferencjami. Zarówno jeden, jak i drugi przypadek można zakwalifikować jako sytuację, w której jednostka nie jest w stanie postapić właściwie, z uwagi na zbyt silne emocje. Różnica polegałaby jedynie na sposobie modelowania danej sytuacji. W pierwszym przypadku silne emocje na tyle zaćmiewałyby ocenę sytuacji przez jednostkę, że nie wiedziałaby nawet, co jest dla niej lepsze (nie znałaby swoich przemyślanych preferencji). W drugim przypadku silne emocje nie pozwoliłyby jej na działanie zgodnie ze znanymi sobie przemyślanymi preferencjami. Tym niemniej należy powiedzieć, że w żadnym z tych przypadków nie mielibyśmy do czynienia z akrazja. Takie rozumienie modelu Cootera zastępowałoby wybór przez jednostkę 
opcji $a$ lub $b$ obiektywną (choć „wewnętrzną”) niemożliwością wyboru $b$. Tym samym nie byłaby to sytuacja akrazji. Zatem pogodzenie modelu Cootera z rozumowaniem Richarda Hare'a wymagałoby bardzo istotnych zmian w modelu.

Donald Davidson proponuje następujący opis akrazji:

Robiąc $b$, osoba działa w sposób nieopanowany wtedy i tylko wtedy, gdy: robi $b$ celowo (intentionally); jest przekonana, że może dokonać alternatywnego działania $a$; ocenia, że biorac wszystko pod uwagę, lepiej byłoby uczynić $a$.

Davidson formułuje również dwa twierdzenia, które zdają się wskazywać, że akrazja nie jest możliwa.

T1. Jeśli osoba chce zrobić $a$ bardziej niż $b$ i jest przekonana, że może uczynić a lub $b$, to uczyni celowo $a$, jeśli czyni celowo $a$ albo $b$.

T2. Jeśli osoba ocenia, że lepiej byłoby zrobić $a$ niż $b$, to bardziej chce zrobić $a$ niż $b^{7}$.

Jeśli przyjrzeć się uważnie twierdzeniom T1 i T2, można dojść do wniosku, że akrazja nie jest możliwa. Nie jest to pogląd Davidsona. Zgodnie z jego rozumieniem akrazji mamy z nią do czynienia w sytuacji, gdy ktoś nie wybiera działania, które lepiej byłoby uczynić biorąc wszystko pod uwage. Davidson rozróżnia sądy wartościujące prima facie i sądy całościowe (all-out). Sąd prima facie przyjmuje następującą formę:

PF: Biorąc pod uwagę $r$, a jest prima facie lepsze niż $b$.

Sądem prima facie może być np. przekonanie, że określone działanie jest bezpieczniejsze albo że określony produkt jest droższy. Identyfikuje on jedną cechę, w której $a$ jest lepsze niż $b$. Tego typu sąd znacznie różni się od sądu all-out:

AO: $a$ jest lepsze niż $b$.

Sąd all-out jest bezwarunkowym stwierdzeniem, że $a$ jest lepsze, niezależnym od konkretnych cech $a$ lub $b$. Nie można go w logiczny sposób wyprowadzić z sądów prima facie. W ujęciu Davidsona sądy prima facie dobrze opisuja proces rozumowania majacy doprowadzić do decyzji. Alternatywne działania ocenia się w świe-

7 D. Davidson, How is weakness of the will possible?, [w:] D. Davidson, Essays on actions and events, Oxford Scholarship Online: November 2003. 
tle kolejnych cech. Jednocześnie jednak nie ma logicznego związku między sądami prima facie (w świetle $r$ coś jest lepsze) i sądem all-out ( $a$ jest lepsze). Nawet jeśli weźmiemy pod uwagę wszystkie cechy, zgodnie z którymi $a$ jest lepsze niż $b$, i otrzymamy sąd biorący wszystko pod uwagę (all things considered), wciąż będzie on różny od bezwarunkowego sądu all-out. Tym samym możemy uznać twierdzenia T1 i T2 za prawdziwe i dopuszczać sytuację akrazji. Jednostka, która będzie przekonana, że $a$ jest lepsze, nie wybierze $b$, ale jednostka nigdy nie osiaga tego typu sądu all-out. Pozostaje na poziomie sądu warunkowego, prima facie. Widzi, że wiele argumentów przemawia za wybraniem $a$, ale nie jest gotowa uznać, że powinna uczynić $a$. Tym samym możliwe jest postępowanie wbrew przekonaniu, że biorąc wszystko pod uwagę, określone działanie jest lepsze. Z przejściem od sądu warunkowego (biorącego wszystko pod uwagę) do sądu all-out łączy się zasada racjonalności, którą Davidson nazywa zasadą powściagliwości (principle of continence) ${ }^{8}$. Zasada ta nakazuje podejmować działanie oceniane jako najlepsze na podstawie wszystkich dostępnych istotnych dowodów. Mimo że akrazja nie jest niemożliwa, to jest nieracjonalna. By można było mówić o akrazji, działanie musi być celowe. Zatem jednostka ma powód, by czynić $b$, powód ten jednak nie jest wystarczający.

Ujęcie akrazji Davidsona daje pogodzić się z modelem Cootera, tym niemniej wymaga on pewnych modyfikacji. Działanie bez przemyślanego wyboru, wyłącznie pod wpływem impulsu, może stanowić akrazję, jeśli przyjmiemy, że spełnia ww. warunki (celowość, świadomość alternatyw, „branie wszystkiego pod uwagę”). Oczywiście w tym przypadku sądy prima facie, których dokonuje, będą stosunkowo nieliczne. Znacznie lepiej w wizję Davidsona wpisuje się druga sytuacja nieopanowanego działania: gdy jednostka jest świadoma swoich przyszłych preferencji, a mimo tego postępuje wbrew nim. W takim przypadku możemy uznać, że warunkowy sąd bioracy wszystko pod uwagę zawiera w sobie zarówno preferencje $r_{0}$, jak i $r_{1}$. Pozwala on porównać impuls chwili i przyszły żal. Racjonalna

8 D. Davidson, How is weakness of the will possible?, dz. cyt. 
(zgodna z zasada powściagliwości) rzeczą byłoby przejść od sądu warunkowego do bezwarunkowej decyzji nt. odpowiedniego działania. Czasem jednak jednostka nieracjonalnie i akratycznie postępuje inaczej.

Interesujące może być pytanie o relację między działaniem maksymalizującym użyteczność jednostki a działaniem zgodnym z zasadą powściagliwości, tj. wybieraniem działania ocenianego (judged) jako najlepszego na podstawie wszystkich dostępnych istotnych dowodów. Możemy wyobrazić sobie dwa sposoby interpretacji zasady powściagliwości w kontekście teorii racjonalnego wyboru.

1. Działanie oceniane jako najlepsze na podstawie wszystkich dostępnych istotnych dowodów jest po prostu działaniem, które jednostka preferuje. Tym samym materialny lub obiektywny aspekt danego działania nie ma dla nas znaczenia, a krzywa użyteczności zawsze wyraża działanie zgodne z zasadą powściagliwości. Tego typu interpretacja sprawiłaby jednak, że zasada straci sens, gdyż każde działanie byłoby z nią zgodne.

2. Nie każde działanie preferowane przez jednostkę $\mathrm{w}$ danym momencie jest działaniem ocenianym jako najlepsze na podstawie wszystkich dostępnych istotnych dowodów. Moga to być na przykład tylko działania wybrane po dłuższym zastanowieniu, w sposób niemotywowany chwilowym impulsem, działania zgodne z długoterminowym interesem jednostki, działania sprawiedliwe itp. Jak wspomnieliśmy powyżej, wpisując zasadę powściągliwości w model akrazji Roberta Cootera, możemy powiedzieć, że działanie zgodne z przemyślanymi preferencjami może być uznane za działanie zgodne z zasadą powściagliwości. Zatem działanie pod wpływem impulsu, przy stopie dyskontowej $r_{0}$ możemy uznać za niepowściagliwe, zgodnym z zasadą powściagliwości będzie zaś działanie zgodne z przemyślanymi preferencjami $r_{1}$.

Warto w tym miejscu dodać, że zasada powściągliwości Davidsona jest sformułowana bardzo ogólnie, pozwalając na bardzo różne interpretacje. 


\section{Podsumowanie}

Na płaszczyźnie teoretycznej modelowanie akrazji Roberta Cootera stanowi odejście od podstawowych założeń ekonomii głównego nurtu. Przenosi on obiekt zainteresowania z działania jednostek na wewnętrzny proces decyzyjny. Preferencje jednostki przestaja objawiać się jedynie poprzez jej (zewnętrzne) decyzje konsumpcyjne. W klasycznym ekonomicznym rozumieniu preferencji odgrywałyby one rolę podobną do sądów all-out w terminologii Davidsona lub sądów wartościujących Hare'a. Tym samym jednostka nie może nie postępować zgodnie ze swoimi preferencjami. Modelowanie samego procesu decyzyjnego pozwala na wprowadzenie preferencji chwilowych, a także spodziewanych przyszłych preferencji. To zaś pozwala na modelowanie akrazji, które w innym przypadku nie jest możliwe. Możemy zatem mieć do czynienia z sytuacja, w której jednostka nie maksymalizuje swojej funkcji użyteczności. Rozważanie dalszych konsekwencji tego typu opisu rzeczywistości wykracza poza ramy tego artykułu.

Modelowanie akrazji przez Roberta Cootera stanowi bardzo interesujaca próbę odejścia od uproszczonego modelu jednostki jako homo oeconomicus. Jednocześnie jest próbą znacznego poszerzenia spektrum zainteresowania (i możliwości modelowania) ekonomii, wciąż posługując się podstawowymi narzędziami teorii racjonalnego wyboru. To zaś może mieć daleko idące konsekwencje dla budowania dalszych modeli mikroekonomicznych.

Jednocześnie przywołanie filozoficznych koncepcji akrazji w połączeniu z opisywanym modelem pozwala przedstawić pełniejszy obraz wspomnianego zjawiska. Filozoficzne interpretacje w oderwaniu od ekonomicznego modelu nie moga być bezpośrednio zastosowane w analizie ekonomicznej; jednocześnie sam model akrazji, pozbawiony filozoficznej podbudowy, nie w pełni opisuje naturę tego zjawiska. 


\section{Summary}

\section{Modelling akrasia}

In general, economics does not deal with the details of a decission process, focusing solely on the result of a given behaviour. Model of akrasia formulated by Robert Cooter allows for modelling of the very decision process leading to a given behaviour therefore widening the scope of interest of economics. It does it by allowing for preferences changing in time and the possiblity of anticiaption of the shape of future preferences. This allows for modelling of lapses, the regret connected with a wrong decision and akrasia (weakness of will) - a acting contrary to one's better judgement. Cooter's model can be reconciled with some of the contemporary philosophical theories of akrasia. Combining an economical model with philosophical theories allows for a fuller understanding of akrasia.

Keywords akrasia, economic, decision making, Aristotle

\section{Bibliografia}

Arystoteles, Etyka nikomachejska, przeł., oprac. i wstępem poprzedziła D. Gromska, Warszawa 1982.

Broome J., Ethics out of economics, Cambridge 1999.

Cooter R., Justice and economic decision making: a model of akrasia, „Social Justice Research" 1990, s. 273-283. http://works.bepress.com/robert_ cooter/121/ (13.02.2016).

Cooter R., Lapses, conflict and akrasia in torts and crimes, „International Review of Law and Economics" 1991, s. 149-164, http://works.bepress.com/ robert_cooter/95/ (13.02.2016).

Davidson D., How is weakness of the will possible?, [w:] D. Davidson, Essays on actions and events, Oxford Scholarship Online: November 2003.

Platon, Dialogi, t. 1, Kęty 1999.

Stroud S., Weakness of will, [w:] The Stanford encyclopedia of philosophy (Spring 2014 Edition), ed. E. N. Zalta, http://plato.stanford.edu/archives/ spr2014/entries/weakness-will/ (17.05.2016). 